\title{
SIII
}

\section{Studies in Second Language Learning and Teaching}

Department of English Studies, Faculty of Pedagogy and Fine Arts, Adam M ickiewicz University, Kalisz

\section{Foreign language education in rural schools: Struggles and initiatives among generalist teachers teaching English in M exico}

\author{
Jesús Izquierdo ${ }^{1}$ \\ Universidad Juárez Autónoma de Tabasco, Villahermosa, Tabasco, M exico \\ https://orcid.org/0000-0001-5605-2318 \\ jesus.izquierdo@ujat.mx \\ Silvia Patricia Aquino Zúñiga \\ Universidad Juárez Autónoma de Tabasco, Villahermosa, Tabasco, M exico \\ https://orcid.org/0000-0002-7223-8582 \\ saquinozuniga@gmail.com \\ Verónica García Martínez \\ Universidad Juárez Autónoma de Tabasco, Villahermosa, Tabasco, M exico \\ https://orcid.org/ 0000-0001-5299-3540 \\ verónica.garcia@ujat.mx
}

\begin{abstract}
In many countries, English as a foreign/second language (L2) teaching has become compulsory in urban and rural public schools. In rural areas, the challenges for the implementation of this state-sanctioned policy have been explored among $\mathbf{L} 2$ teaching specialists. However, this mixed-methods study considered a different teacher group and examined the struggles and initiatives of generalist teachers who are obligated to teach English in rural schools. To this end, data were collected from 115 teachers in 17 rural secondary schools in the Southeast of M exico. First, the participants completed a survey with closed-ended questions that elicited information about teacher education, teaching experience and knowledge of the rural school system. Then, a
\end{abstract}

${ }^{1}$ Correspondence concerning this article should be sent to the first author. 
subsample of participants completed an individual thematized semi-structured interview. They were selected on the basis of $L 2$ teacher education involvement. In the survey data, response patterns were identified using frequency analyses. The interview data were analyzed using categorical aggregation. The data revealed that the generalist teachers struggle with $L 2$ professionalization, sociocultural and instructional challenges. Nonetheless, only few participants have been engaged in $L 2$ teacher education which could help them overcome these challenges. Instead, they rely upon limited strategies to counteract the day-today challenges at the expense of effective $L 2$ teaching practices.

Keywords: language policy; language planning; English as a foreign language; rural education; teacher education

\section{Introduction}

In many countries, English language learning in public education has become state-mandated despite a heated debate on the linguistic, economic, social and cultural benefits and drawbacks of this policy (Crystal, 2012; Roldán \& Peláez, 2017). As a result, in higher education, many universities offer undergraduate and graduate programs that privilege English as a second/foreign language (L2) instruction over other languages or promote content and English language integrated learning (Arias \& Izquierdo, 2015; Woodend et al., 2019). As for elementary and middle school education, many countries have sanctioned English as an L2 learning through various layers of public education and established specific language attainment goals, instructional guidelines and evaluation criteria under the Common European Framework (Kihlstedt, 2019). In this way, educational policy makers and stakeholders are enacting English as an L2 teaching across the levels of public education.

Undoubtedly, these reforms seem promising for public education but bring with them several challenges, particularly in rural areas. In the rural elementary and secondary schools of Latin America, for instance, there is often a shortage of L2 teaching specialists (Bonilla \& Cruz-Arcila, 2014; Coelho \& Henze, 2014; Roldán \& Peláez, 2017). In the absence of L2 specialists, in rural schools, generalist teachers are obligated to deliver English instruction despite resistance (Coelho \& Henze, 2014; Hernández \& Izquierdo, 2020). Different from L2 specialists, generalist teachers hold general pedagogical knowledge, deliver subject-matter instruction across all areas of the curriculum, lack formal L2 teacher preparation and often lack L2 competence. As these teachers cover all areas of the curriculum with the same learners, they spend many hours with them throughout the day and the school year (Hernández \& Izquierdo, 2020; Zein, 2017). 
Nonetheless, the challenges that generalist teachers in rural schools encounter to accomplish $\mathrm{L} 2$ policy require attention in industrialized and developing countries (Coelho \& Henze, 2014; Hansen-Thomas et al., 2016; Hernández \& Izquierdo, 2020; Zein, 2017). Also, the strategies that they implement to counteract those challenges need documentation. To this end, this sequential explanatory mixed-methods study collected data from generalist teachers who deliver English L2 instruction in rural secondary schools in the Southeast of M exico. The quantitative and qualitative data provide insights into the strategies that these teachers rely upon for overcoming social, professional and instructional challenges for the delivery of $\mathrm{L} 2$ instruction in their schools. The results reveal that generalist teachers are in urgent need of professionalization projects for the development of the $L 2$ teaching competence and proficiency which they require for the enactment of the English language teaching policy in rural areas.

\section{Literature review}

Educational systems worldwide are experiencing remarkable $L 2$ education reforms. These reforms are promoting state-sanctioned educational policies that favor the learning of English in public education in countries where English is neither the native nor the official language (Crystal, 2012). Despite the establishment of the English language in the form of linguistic imperialism, the learning of English constitutes a major curricular change in countries that see in this language a benefit for international interaction and economic growth (Woodend et al., 2019). Nonetheless, in many parts of the world, the teaching of English and the attainment of the L2 curricular goals in public elementary and secondary schools face many challenges (Coelho \& Henze, 2014; Giannikas, 2011; Izquierdo et al., 2016; Lightbown \& Spada, 2020; Ramos Holguín \& Aguirre M orales, 2016; Roldán \& Peláez, 2017).

In rural areas, the sociocultural characteristics of the schools, teachers, parents and learners bring about additional challenges that counteract attainment of the $L 2$ curricular expectations (Hossain, 2016; Lamb, 2012). While the conditions may vary from industrialized (Hansen-Thomas et al., 2016) to developing countries (Bryan \& M cLaughlin, 2005), in rural communities, learners often face a shortage of school choices. In the available schools, some teachers are underqualified, teachers work in overcrowded classrooms, schools often lack educational resources and appropriate facilities, and some teachers may teach various grades in the same classroom at the same time. Moreover, as families are poorly remunerated, children work and have limited study time and educational resources (Bonilla \& Cruz-Arcila, 2014; Hossain, 2016; Pinzón, 2014; Roldán \& Peláez, 2017).

As for L2 instruction, in the rural communities of Latin America, for instance, inhabitants often object to learning this language as it does not figure high 
in their life projects (Coelho \& Henze, 2014). M oreover, educators and stakeholders, who are tightly connected with rural educational institutions, regard the $L 2$ policy as a mere fallacy and as an unachievable decontextualized goal (Ramos Holguín \& Aguirre M orales, 2016; Roldán \& Peláez, 2017). Instead, rural community learners and inhabitants prioritize public education courses which promote the development of competencies that contribute to the ability of male learners to work in the agricultural sector and of female learners to obtain employment in nearby villages (Pinzón, 2014). Scarce exposure to English outside of the class in rural settings further fosters apathy towards $L 2$ instruction among learners (CoeIho \& Henze, 2014). Rural learners do not see the practical use of the English lessons because teachers place heavy emphasis on error correction and decontextualized grammar learning (Pinzón, 2014). Additionally, learner and teacher absenteeism in schools constitutes a common trend that contributes to the learners' educational dissatisfaction. In light of these issues, it comes as no surprise that rural learners show less $L 2$ learning commitment and achievement in comparison to their peers in urban areas (Hossain, 2016; Lamb, 2012; Zein, 2017).

On the language teachers' side, the aforementioned sociocultural conditions and low salaries demotivate qualified $\mathrm{L} 2$ educators from a career in the rural context (Ramos Holguín \& Aguirre M orales, 2016). This is of major concern in an era when the recruitment of language-teaching professionals has become an indisputable challenge in industrialized and developing countries (Coelho \& Henze, 2014; Kissau et al., 2019). For the 12 educators who already work in public schools, the new educational policies place high demands in terms of $L 2$ proficiency and L2 pedagogy (König et al., 2016). The L2 proficiency of rural English teachers is often poor (Coelho \& Henze, 2014). Thus, they need to pursue $L 2$ competence development courses for the use of English as the object of study and the means of communication inside and outside of the L2 class. With respect to $L 2$ pedagogy, in-service $L 2$ teachers have to give up the traditional grammar-oriented English teaching practices that characterize education in rural schools (Pinzón, 2014). Instead, under the mandate of the educational reforms, teachers need to adopt pedagogical practices that facilitate learners' attention to meaningful language and the creation of valuable $\mathrm{L} 2$ communicative conditions (Izquierdo et al., 2016). In urban areas, training for L2 competence and L2 pedagogy improvement is accessible through institutional or private teacher development programs (Coelho \& Henze, 2014). Nevertheless, in rural areas, educators are often deprived of such $\mathrm{L} 2$ teacher education opportunities (HansenThomas \& Grosso, 2015; Zein, 2017).

M ore challenges arise when the educational system enforces the $L 2$ policy in rural schools which cannot count upon trained L2 educators (Coelho \& Henze, 2014; Ramos \& Aguirre, 2016; Roldán \& Peláez, 2017). Therefore, already hired 
generalist teachers, who do not relate their teaching identity to the $\mathrm{L} 2$ teaching profession, are forced to deliver L2 instruction (Hernández \& Izquierdo, 2020; Zein, 2017). In these schools, two types of generalist teachers face the compulsory implementation of L2 teaching. One group of teachers may hold some knowledge of the $L 2$ and teaching certifications in areas of the curriculum that exclude L2 pedagogy (Hansen-Thomas \& Grosso, 2015; Zein, 2017). The other group has general pedagogical training but lack both L2 competence and L2 teacher education (Coelho \& Henze, 2014; Hernández \& Izquierdo, 2020). Evidence from studies that have focused on generalist teachers indicates that their appreciation of their own L2 pedagogy underqualification deteriorates their self-perception of their teaching effectiveness and self-esteem (Hansen-Thomas et al., 2016). This perception emerges from the need of metalinguistic knowledge to deliver appropriate language-related explanations. It also results from their awareness that general pedagogical training is insufficient for the creation of engaging L2 lessons (Carr, 1999; Zein, 2017).

While in some educational contexts generalist teachers have no institutional support for the delivery of $L 2$ education, in other contexts they receive technology-enhanced instructional packages which could help them compensate for their lack of $L 2$ competence and $L 2$ teacher education (Hansen-Thomas \& Grosso, 2015; Roldán \& Peláez, 2017). These instructional aids aim to make "learning more pleasant to the students because they offer a reality of experiences, which stimulate self-activity and imagination" (Hossain, 2016, p. 3). M oreover, they can provide exposure to meaningful L2 input and output opportunities whereby learners can realize the importance of $\mathrm{L} 2$ learning during secondary education. Nonetheless, for the effective implementation of the official technology enhanced packages, the rural school educators often lack proper training on the use of technology or do not have access to the necessary facilities and equipment for their implementation (Hossain, 2016; Roldán \& Peláez, 2017).

In sum, generalist teachers face many challenges in the delivery of English L2 education in rural schools. To date, only a handful of studies have been conducted with this group of teachers. Hansen-Thomas et al. (2016), for instance, explored the development of $\mathrm{L} 2$ teaching competencies among generalist teachers through peer collaboration with L2 specialists. Also, Hossain (2016) examined the challenges that generalist teachers face in the teaching of English in rural areas. These studies have provided some valuable insights into their perception of self-efficacy and motivation, but questions arise regarding the daily challenges that they face in English teaching in their school settings. Furthermore, little is known about the strategies and actions they rely upon on a daily basis for the implementation of English language teaching policy. Empirical evidence on these issues is valuable as the choices teachers make in their daily educational 
practices are not only decisive for the effective implementation of the $L 2$ educational policies (Hernández \& Izquierdo, 2020; Roldán \& Peláez, 2017) but they also play a key role in teacher attrition rates in the rural context, where teacher recruitment is a major concern (Hancock \& Scherff, 2010; Kissau et al., 2019; Ramos Holguín \& Aguirre M orales, 2016). In order to explore the struggles and initiatives of generalist teachers as they face the compulsory teaching of English in rural areas, this study addresses the following two research questions:

1. What are the challenges that generalist teachers encounter on a daily basis in the delivery of English L2 instruction in rural public schools?

2. On what strategies do they rely for the delivery of English $L 2$ instruction in rural public schools?

\section{Method}

\subsection{Research design}

In order to answer the research questions, a sequential explanatory mixedmethods study was conducted (Creswell, 2018). First, a survey was administered to a large group of generalist secondary school teachers who are required to teach English in rural areas of the Southeast of M exico. Through the survey, quantitative data on their teacher education and teaching conditions were collected. Then, a sub-sample of teachers, who showed some or no participation in L2 teacher education and English learning courses in the survey, took part in an interview. In the interview, they provided qualitative data on the challenges of rural $\mathrm{L} 2$ education and the strategies they put in place.

\subsection{Context and participants}

In M exico, public secondary education can be completed in general, technical and tele-secondary schools. All schools follow the same national curriculum. General and technical schools are often located in urban areas or town suburbs, whereas tele-secondary schools are in rural areas. According to the Ministry of Education (Secretaría de Educación [SE]), tele-secondary schools serve $50 \%$ of the learner population nationwide and are widely distributed across the 32 M exican states (SE, 2011). In the Southeast of M exico, the context of this study, $37 \%$ of the learner population completes secondary education in tele-secondary schools, whereas 35\% attends general secondary schools and $28 \%$ goes to technical schools (SE, 2017).

In general and technical secondary schools, specialist educators teach each area of the curriculum. In the case of $L 2$ instruction, each school counts on 
one or more English teachers. They go from classroom to classroom and deliver English lessons across the three grades of secondary education (Izquierdo et al., 2016). In the tele-secondary schools, however, one generalist teacher covers all the areas of the curriculum with the learners of one secondary school grade throughout the entire school year (Hernández \& Izquierdo, 2020). In order to assist the generalist teachers with the delivery of each area of the curriculum, the $M$ inistry of Education broadcasts televised lessons and offers online educational packages (https://telesecundaria.sep.gob.mx) and free textbooks. Due to the use of technological resources such as televised programs and web-based resources in the delivery of the content of each area of the curriculum, these schools are called tele-secondaries. In the case of English, the generalist teachers should first watch the televised lessons with their learners and then provide extensive $L 2$ practice through the integration of the textbook and educational packages.

In M exican rural areas, the conditions of public schools vary from one school to the next (Bryan \& M cLaughlin, 2005). In the case of tele-secondary education, where a school has only two generalist teachers, learners from two different grades are often grouped in the same classroom and work with the same teacher throughout the year. Due to this variability in the conditions of the rural secondary schools, non-probabilistic sampling was used for the teacher sample selection. Upon consideration of convenience sampling, four conditions were met: The participating teachers would work in tele-secondary schools with the three grades of secondary education, the selected teachers should teach one grade only, the school should have two sections of each secondary grade, and schools would need to be scattered across the four geopolitical areas of the Southeast of M exico. These criteria favored the homogenization of the school conditions among the participants and created conditions for generalizable results among the teacher sample. Based on these criteria, 17 secondary schools were selected for the study. The research team first contacted the school superintendents and principals, who invited all school teachers to a meeting in their schools. During the meetings, the research team informed all teachers of the purpose, data collection instruments and ethical procedures of the study.

For the quantitative phase, only the 115 teachers who signed a consent form were considered. Approximately similar numbers of Grade 1 (36\%), Grade 2 (32\%) and Grade 3 (32\%) teachers constituted our quantitative sample. Their average age was 41 years old, and, on average, they had been in the rural secondary school system for 16 years. Most participants were female teachers (53\%). Their schools were situated in small villages in the Southeast of M exico. The distance between the rural schools and the researchers' university varied from 27 to 159 kilometers. Further details on the participants' educational and teaching profiles are presented in the results section. 
For the qualitative phase of the study, only nine participants provided written consent for an individual interview. From this group, four teachers were selected on the basis of some or no participation in L2 teacher education and English learning courses. In the following sections, pseudonyms are used for each interviewee. As per the participants' explicit request, details on their school affiliation are omitted.

Lydia had worked in the rural secondary school system for 27 years, the largest number of years among the interviewees. Her undergraduate studies were in the area of administration. She did not report attendance of $\mathrm{L} 2$ teaching or English learning courses. She indicated knowledge of the foundations that underpin English language learning in secondary education and of the English materials from the M inistry of Education. Nonetheless, she had no knowledge of the Common European Framework.

Celia held a BA in Education and had been in the rural secondary school system for 24 years. She reported knowledge of the curricular foundations of English learning in secondary education, the Common European Framework and the $\mathrm{L} 2$ materials from the Ministry of Education. She had attended an English language learning course in a private institution but had not been involved in any kind of $L 2$ teacher education seminar or workshop.

Similar to Celia, Juan had earned a BA in education and had been in the rural secondary school system for 24 years. Nevertheless, Juan indicated not knowing the foundations of English learning in secondary education or the Common European Framework but knew about the $L 2$ materials from the M inistry of Education. He had attended a formal English language learning course and reported that he had autonomously been learning English and about English language teaching.

$M$ artha had a BA in education and had been in the rural secondary school system for only eight years. Different from the other interviewees, M artha did not only know the foundations of English language teaching in secondary education and the Common European Framework, but she had also attended L2 competence development and $L 2$ pedagogy courses. Specifically, she had obtained a university certificate in English language learning that lasted eight semesters and had earned a 120-hour certificate in English language teaching from a higher education institution. With respect to the $L 2$ materials from the M inistry of Education, $M$ artha indicated she knew about them but preferred not to use them.

\subsection{Quantitative data collection instrument: Survey}

This instrument included 17 closed-ended questions that were organized into six sections. Sections 1 through 3 elicited information about the participants' experience and knowledge of the tele-secondary school system. Specifically, 
these sections included questions about their past and current teaching experience (Section 1), the secondary school curriculum and its principles for the teaching of English (Section 2), and the M inistry of Education's instructional resources (Section 3). Then, the survey had a set of questions about the participants' English language learning experience (Section 4) and attendance of language teaching workshops and seminars (Section 5). Finally, teachers were presented with questions about their willingness to participate in $L 2$ competence development and L2 pedagogy courses (Section 6). The initial version of the survey was conceptualized by the first author and then analyzed for construct and ecological validity (Field, 2017) by the co-authors, who served as experts due to their research experience with tele-secondary school teachers and their knowledge of the public secondary school curriculum. After the analyses, changes were made in Sections 2 and 3 following the recommendations from the experts. The participating teachers completed the final survey version in Spanish (see Appendix for the English version) within ten minutes during the first visit of the research group.

\subsection{Qualitative data collection instrument: Individual interview}

A thematized semi-structured interview (Creswell, 2018) was conducted to expand upon the participants' survey answers. Three central themes, organized in logical sequence, were explored: 1) the curricular demand for compulsory English language learning instruction in rural secondary schools, 2) the challenges in the delivery of $L 2$ instruction on a daily basis, and 3) the individual strategies for the compliance with this curricular demand. The research team identified these themes on the basis of the research questions, the literature review and the prompts in the initial survey. Each interview theme included three start-off open-ended questions, which met construct and ecological validity criteria as determined by the group of experts (Creswell, 2018). During the interview, all the participants were asked the three start-off questions. Then, emerging personalized questions were used for a deeper exploration of the participants' initial responses. Each teacher was interviewed individually for about 30 minutes in a quiet school classroom. All interviews were conducted in Spanish by a trained member of the research team and audio-recorded.

\subsection{Data analysis procedures}

The survey responses were entered into Excel spreadsheets by a research assistant. A second research assistant crosschecked the spreadsheet data with the survey answers. Using the statistical software SPSS version 25, frequency distribution analyses were run (Field, 2017). Through these analyses, response patterns were identified for 
post-secondary education, interest in L2 teacher education, knowledge about English language learning in tele-secondary education and English teaching conditions.

The interviews were transcribed verbatim with a Word processor by a research assistant. Then, the transcripts were crosschecked against the audio-recorded interviews by the first author. The Word files were imported into Atlas.ti version 8.4.4 for the completion of categorical aggregation analyses (Creswell, 2018). Following this procedure, the data from the four informants were integrated and treated holistically for the identification of emerging categories. During the first transcript analysis, 118 excerpts were coded under nine categories. For reliability purposes, these results were discussed with a qualitative research specialist. After the discussion, the texts were re-coded for categorical reduction (Creswell, 2018) and three main categories of analysis were established: sociocultural factors, professionalization and L2 instruction. Then, within each main category, challenges and strategies were identified. Using the reduced categorization system, a total of 141 excerpts were identified in the interviews during the second coding: Lydia ( $\mathrm{N}=26)$, Celia ( $\mathrm{N}=38)$, Juan $(\mathrm{N}=24)$ and Martha $(\mathrm{N}=53)$.

\section{Results}

In the following sections, the survey analysis results are first presented, followed by the interview data findings.

\subsection{Survey data}

In the quantitative data, the following survey response patterns were observed.

\subsubsection{Post-secondary education}

The survey data indicated that $95 \%$ of the generalist teachers held either undergraduate or graduate degrees in education or educational studies. Specifically, out of the $63 \%$ of the generalist teachers with undergraduate degrees, eight had earned a BA in disciplinary areas such as biology, administration, law or veterinary medicine. Among the $37 \%$ of the generalist teachers with $M A(N=37)$ or $\mathrm{PhD}(\mathrm{N}=6)$ studies, the survey revealed that three of them had pursued graduate degrees in law or natural sciences.

\subsubsection{L2 education}

The generalist teachers had received three years of public English language instruction during the completion of secondary education (Izquierdo et al., 2016). 
While in the survey $89 \%$ of the generalist teachers expressed interest in attending English language courses and L2 teacher education seminars, only $17 \%$ had undertaken the completion of at least one course for the improvement of their English language competence or of their $L 2$ pedagogical knowledge. Among them, one had completed a BA in modern language studies with a concentration on foreign language teaching.

\subsubsection{Familiarity with the 12 curricular demands}

The survey revealed that about $83 \%$ of the generalist teachers reported knowing the learning principles and teaching/evaluation practices that their school curriculum states for the English class. Nonetheless, about $43 \%$ of the teachers were unaware of the $\mathrm{L} 2$ proficiency benchmarks that their learners are expected to reach by the end of each secondary school grade on the basis of the Common European Framework. M oreover, $62 \%$ of the generalist teachers reported not using the M inistry of Education's L2 educational resources.

\subsubsection{English language teaching self-confidence}

A noticeable response pattern in the survey data related to the detriment in the level of $\mathrm{L} 2$ teaching confidence among the generalist teachers throughout the secondary school grades. In their answers, it was observed that $80 \%$ of the generalist teachers felt confident teaching the content of the English curriculum in Grade 1 . Nonetheless, the number of confident teachers drastically decreased with respect to Grade 2 (37\%) and Grade 3 (24\%).

\subsection{Interview data}

In this section we describe the challenges and strategies that were documented under the three main categories of analysis that emerged from the interview data.

\subsubsection{Sociocultural factors}

In this category, 19 excerpts for challenges and 12 excerpts for strategies were identified. With respect to the challenges, the interviewees systematically referred to the economy, infrastructure and identity affiliation of rural communities as indisputable barriers to the appropriate compliance with the L2 educational policy (all the extracts are translations from Spanish): 


\section{Extract 1}

Many children work after school because they do not receive financial aid from the government. Those who have financial aid do not invest in educational resources; instead, they spend the money on food and groceries for their families. (Celia)

\section{Extract 2}

These children do not have computers or internet... Our school is in a remote community where there are no Internet networks and we often experience blackouts. (Juan)

\section{Extract 3}

The learners are not interested in learning English. "What do I need English for? I'm not a gringo and I will stay in my village" is what they often say. (Juan)

With respect to the economic conditions, the teachers indicated that rural families struggle under low income. This leads to a series of interrelated educational obstacles. As learners work after school time, they often lack time for assignment completion. Additionally, learners with government financial assistance spend the financial aid on family expenses and see the purchase of complimentary L2 materials as irrelevant, as Extract 1 illustrates. With respect to infrastructure, Extract 2 shows that rural communities often face power and internet access constraints. Under these conditions, the learners have limited study time or lack power to use technological resources for independent study or the completion of assignments using the technology-enhanced materials from the Ministry of Education. This hinders timely coverage of the $\mathrm{L} 2$ curriculum as teachers need to spend more time than expected covering the content of each curricular unit during class time. Finally, a major sociocultural constraint to $L 2$ learning among rural learners relates to their identity perception, as revealed by Extract 3 . The teachers explained that rural learners rarely believe that they will come into contact with English speakers because they often settle down in their rural community and conceive of their community as detached from the English-speaking world. M oreover, they do not see themselves as individuals who require English for academic purposes as they often disregard studies beyond secondary education. In order to counteract these limitations to English L2 learning, the teachers indicated that they sometimes engage in brief discussions with the learners about two sociocultural aspects of rural life: migration and the need for better paid jobs, as Extract 4 indicates:

\section{Extract 4}

Some people from this rural community go to the USA looking for a better life. Thus, they need at least some knowledge of English to communicate and work. (Lydia) 
With respect to migration, teachers acknowledged that some rural community inhabitants either move to major international tourist cities or migrate to the United States. In light of the former situation, teachers discuss with their learners the need of some basic communicative skills for employment in the tourist sector. As for the latter case, teachers raise learners' awareness of the need of basic communicative skills for workers who migrate to the United States. To meet these needs, teachers consider the study of English vocabulary and phrases that their learners will require to greet people, introduce themselves or sell/buy products. As for the relevance of English in the pursuit of post-secondary education, the interviewees acknowledged that, in the English lessons, they try to help rural learners realize that life quality improvement can be reached through employment in professional jobs that demand some knowledge of English. M oreover, to help the learners realize the value of $L 2$ reading comprehension, they implement translation tasks with short academic texts that the learners might encounter in senior high school or university programs.

\subsubsection{Professionalization}

In this category, 16 excerpts for challenges and 13 excerpts for strategies were recorded. As for the challenges, all the participants clearly identified themselves as generalist teachers and felt equally committed to all areas of the secondary education curriculum. Moreover, for some of them, the delivery of the English L2 curriculum is far beyond their general pedagogical knowledge and their own interest, as Lydia and Juan indicate in Extracts 5 and 6:

\section{Extract 5}

We [generalist teachers] face a major challenge in the teaching of English in the rural schools... We don't even have the basic vocabulary; we have no training or skills to teach English. (Lydia)

\section{Extract 6}

Since we don't know English, its teaching is not a priority for us. (Juan)

For the development of the $L 2$ and $L 2$ teaching competencies, the interviewees indicated that they require institutionalized seminars from the M inistry of Education. Nonetheless, they reported that such courses are scarce since the institution is committed to the provision of courses that focus on the generalities of the curricular reforms of secondary education. When 12 teacher education courses are offered, they are often delivered by peers who are not $\mathrm{L} 2$ teacher educators, or through short webinars, which do not foster $L 2$ teacher development. 
A shared viewpoint among the participants was that the $\mathrm{L} 2$ teacher professionalization challenge can only be overcome with the teacher's interest, individual initiatives and time investment. During the interview, only one participant acknowledged enrollment in various $L 2$ competence development options. They included long-term language learning certifications, short L2 courses, short stays in English-speaking countries, or online L2 learning tutorials. As for $L 2$ teaching competence development, only this participant indicated the completion of a long-lasting L2 pedagogy course.

\subsubsection{L2 instruction}

In this category, the largest number of excerpts was identified (challenges: 31 , strategies: 46). In the interviews, the participants highlighted multiple instructional difficulties that revolve around four interrelated issues: high L2 curricular demands, lack of sensitivity to the reality of rural schools, inadequacy of the instructional resources and prioritization of other curricular subjects over L2 instruction. With respect to curricular demands, the interviewees acknowledged that the educational reforms have set overwhelming expectations in terms of the $\mathrm{L} 2$ competence that the learners need for the completion of secondary education and in terms of the $L 2$ competence that the generalist teachers are required to deliver the $\mathrm{L} 2$ lessons. They explained that, as generalist teachers, they hold limited notions of the L2, as Extracts 5 and 6 illustrated. Second, rural learners complete elementary education in their communities and come to secondary education without the expected L2 pre-requisites, as Lydia indicates in Extract 7:

\section{Extract 7}

I feel our official textbooks are too advanced as they assume learners have taken English in kindergarten and elementary school. (Lydia)

Third, some rural learners lack proper linguistic competencies in their mother tongue, Spanish, as Celia indicates in Extract 8:

\section{Extract 8}

We work in a rural community where children speak Spanish with many deficiencies. Then, we have to teach them English! ... Often the situations and contexts in the materials do not relate to the life of the learners. (Celia)

M oreover, the interviewees stated that this lack of sensitivity permeates the televised lessons, technology-enhanced materials and books from the M inistry of Education. They felt these materials include content beyond the L 2 abilities of teachers and students and often present contexts and situations which are irrelevant to 
rural learners. Under these challenges, the interviewees see the preparation and delivery of $\mathrm{L} 2$ lessons as time-consuming, and often prefer dedicating that time to the implementation of maths and first language literacy lessons.

During the interviews, the generalist teachers discussed several initiatives that counteract most of the aforementioned instructional challenges. These initiatives included avoidance of the official materials, coverage of limited L2 vocabulary (see Extracts 10-11), reliance on internet-based video-tutorials (see Extract 10) and use of translations (see Extracts 9-10). According to the interviewees, the official materials are relevant only to identifying the 12 topics that they need to teach. Nonetheless, the topics are covered by activities from books and websites that are appropriate to the teachers' $\mathbf{L} 2$ competence. The participants reiterated that these activities focus on vocabulary and grammar-rule learning in short dialogues. For the implementation of these tasks, the teachers often rely on projecting videos with explanations in Spanish; the generalist teachers felt these materials are particularly valuable as they provide specialized explanations or accurate word/sentence pronunciation that are beyond their $\mathrm{L} 2$ knowledge. For the interviewees, these tasks integrated vocabulary with which they felt comfortable due to their level of English and activities that required basic L2 knowledge from the learners themselves. Often, they indicated their teaching emulated the $L 2$ activities they had experienced as L2 learners and which they considered effective for vocabulary and grammar learning. Two interviewees also explained that their L2 teaching was based on their analysis of what they considered effective $L 2$ teaching practices that they had developed through trial and error:

\section{Extract 9}

I translate the book and activities into Spanish and then project the translations ... When there's power outage, I tell the students: Ok, pull out your dictionary, we're going to translate the text in the book... Sometimes I ask them to work in groups and translate the texts ... In these groups, I appoint a student leader who reports back to me whether all of them contributed. (Lydia)

\section{Extract 10}

I teach basic vocabulary, as if they were in elementary school: colors, vocabulary about the family, fruits, jobs...I play video tutorials ... Students translate the vocabulary and check the pronunciation. (Celia)

\section{Extract 11}

I teach vocabulary in context. Then, they make vocabulary presentations. We watch videos where they check the pronunciation of the words... When I play an audio, I stop it and ask them for the words they understood. This way, they learn vocabulary that they can use if they go to college. (Celia) 


\section{Discussion}

Through two research questions, this study examined the challenges and initiatives of generalist teachers who are obligated to deliver state-sanctioned English L2 instruction in rural secondary schools in the Southeast of M exico. Our evidence substantiates the claim that, despite attending to a significant proportion of the student population, rural generalist teachers constitute a forgotten minority of the public education sector in terms of institutional support. Such support could help them comply with the demands of their school curriculum (Hansen-Thomas et al., 2016; Hossain, 2016; Zein, 2017; Ramos Holguín \& Aguirre M orales, 2016).

In terms of $L 2$ education, policy makers and educational stakeholders need to recognize the fact that the lack of $L 2$ preparedness amongst generalist teachers constitutes an undisputable challenge to the implementation of the English language teaching policy and the attainment of the 12 curricular aims in rural schools. Our evidence suggests that the L2 educational policies, curricular guidelines and educational packages available do not help teachers compensate for their lack of $L 2$ competence, a sound understanding of instructed $L 2$ acquisition and $\mathbf{L} 2$ teaching strategies. In the absence of all these aspects of $\mathbf{L}$ teacher knowledge, our participants have taken up two worrisome practices.

One initiative relates to their professionalization. Despite the urgent need of $\mathrm{L} 2$ teacher preparedness, in our study only a few generalist teachers have committed themselves to the development of $L 2$ competence and $L 2$ pedagogical knowledge. This behavior diverges from the actions of generalist teachers in other international contexts who have pursued L2 teacher education initiatives for the enhancement of $\mathrm{L} 2$ teaching knowledge and skills (Hansen-Thomas \& Grosso, 2015; Pinzón, 2014; Zein, 2017). Explanations for this behavior are found in the interviews, where our participants openly acknowledged that, as generalist teachers, they see themselves equally committed to all areas of the curriculum. For them, L2 instruction constitutes just another subject area to teach. Under time and financial constraints, they then privilege teacher education that focuses on the principles of the educational reforms and subject-matter areas such as Spanish reading comprehension, mathematics and the sciences, as these curricular areas constitute the focus of national standardized tests (Saulés, 2012; SE, 2016).

The second initiative relates to the implementation of instructional strategies that may work to the detriment of L2 learning in rural schools. For instance, in an attempt to consolidate the learning of basic $L 2$ knowledge among their learners, the generalist teachers disregard the official textbook and technology-based materials. Instead, they opt for resources that are less challenging for them and their learners. The content of these resources alters the flow of the linguistic and communicative features in the English curriculum. Also, teachers 
make individualized choices with respect to the $\mathrm{L} 2$ content that is covered and left out. This brings serious challenges for the teacher who will work with the learners the year after. Finally, teachers select $L 2$ instructional tasks that do not foster communicative use of English. Instead, these tasks lead to the systematic use of translations, decontextualized grammar rule practice, vocabulary memorization and error correction that foster apathy towards the English class among rural learners (Pinzón, 2014; Ramos Holguín \& Aguirre M orales, 2016; Yunus \& Abdullah, 2011).

In terms of sociocultural challenges, as in other international contexts (Ramos Holguín \& Aguirre M orales, 2016; Roldán \& Pelaez, 2017; Zein, 2017), our generalist teachers perceived the $\mathrm{L} 2$ educational policies as rigid and detached from the reality of $L 2$ education in rural communities. In M exico, rural learners advance through public education with academic and language learning flaws that have accumulated during their transit throughout the educational offerings available to them (Bryan \& M cLaughin, 2005). These flaws relate not only to deficient subject-matter learning in elementary education. They are also associated with poor development of their mother tongue and lack of sufficient knowledge of the world outside of their rural communities. Our data indicate that the generalist teachers are quite aware of these and other sociocultural challenges that pertain to the L2 academic achievements and failures of their rural learners. Because of these challenges, one laudable initiative of our generalist teachers is that they consider the learners' family, social, cultural and emotional problems in the organization of their English lessons.

For instance, as the rural learners lack some first language literacy skills, teachers implement translation tasks where the learners do not only cover the grammar and lexis of the $L 2$ but also learn about the proper use of their mother tongue. Also, as many family members from the rural South of M exico migrate to the United States (Bryan \& M cLaughlin 2005), the generalist teachers dwell upon their learners' need to maintain communication with their parents or siblings abroad. This sociocultural value that our generalist teachers give to the learning of English in rural schools and their efforts to help their learners gain some $L 2$ proficiency contrasts with the perceptions of teachers in the rural areas of other Latin American countries (Bonilla \& Cruz-Arcila, 2014; Coelho \& Henze, 2014; Ramos Holguín \& Aguirre M orales, 2016; Roldán \& Peláez, 2017). For our generalist teachers, it is clear that the geographical proximity between M exico and the United States, as well as the border-crossing conditions of M exican migrants, draws an important social scenario for the role of English language learning in rural learners' lives. Therefore, they feel morally compelled to provide their learners with some L2 knowledge in case they or their relatives migrate.

The study then provides evidence of some drawbacks of the enactment of $L 2$ education policies in rural areas. However, the mixed-methods approach 
of the study brought about various methodological challenges. For instance, the quantitative sampling criteria allowed for the selection of teachers across comparable rural schools, disregarding the fact that the conditions of rural schools substantially vary from one region to the next. In order to take into account rural school differences and increase the generalizability of the results (Field, 2017), stratified or cluster sampling could be considered in future research. As for the qualitative insights of the study, they come from a small number of teachers who participated in short interviews. These insights result from data that could have been corroborated through classroom observations. However, the generalist teachers rejected the idea of being observed, most likely for reasons that have been addressed in previous L2 classroom-based studies (Izquierdo et al., 2016). Nonetheless, the use of various qualitative data collection instruments deserves consideration for the triangulation of qualitative evidence in future research.

\section{Conclusion}

The generalist teachers in this study reflect and act upon the sociocultural, professionalization and instructional challenges around the English language teaching policy in their rural schools. As in other international contexts (Ramos Holguín \& Aguirre M orales, 2016; Zein, 2017), they are aware of their need of $L 2$ teacher education, but $\mathrm{L} 2$ teaching preparedness does not figure high among their initiatives. Instead, they prefer teacher education that provides them with general information about the secondary school curriculum, educational reforms and the pedagogy of the various subject-matter areas they teach in the learners' first language. Under these circumstances, they rely upon teaching practices that help them circumvent the $L 2$ competence and $L 2$ pedagogy demands of their school curriculum. But these $L 2$ professional and teaching initiatives raise concerns about the effectiveness of the implementation of $L 2$ educational policies in rural schools.

L2 teacher education options are scarce in rural areas (Coelho \& Henze, 2014; Hansen-Thomas \& Grosso, 2015), and the institutional L2 teacher training available is not sufficient. Moreover, teachers often face time limitations for teacher education outside of their teaching schedule and rural school settings. Therefore, the organization and promotion of $L 2$ teacher education programs for generalist teachers in rural areas should be a major concern for policy makers, educational stakeholders and higher education institutions. Upon consideration of previous research that focused on $\mathrm{L} 2$ teacher development in rural areas (Hansen-Thomas \& Grosso, 2015; Pinzón, 2014), the L2 preparedness challenge among generalist teachers can be overcome through the implementation of teacher projects that unfold in the rural schools. Their implementation can consider the integration of teacher teams and L2 educator specialists. Educational projects which 
foster collaboration between generalist teachers and L2 specialists constitute effective teacher education strategies which promote collegial critical inquiry, focused dialogue and in-depth reflection (Hansen-Thomas \& Grosso, 2015).

Furthermore, as generalist teachers cover subject matter and $L 2$ teaching with the same learners during the complete school year, they could engage in collaboration with $\mathrm{L} 2$ specialists and develop teaching projects where they work on the integration of English with other areas of the curriculum. The integration of $\mathrm{L} 2$ and subject matter teaching is complex but achievable and gratifying (Arias $\&$ Izquierdo, 2015). Through the integration of language and content learning, generalist teachers can foster the interrelated learning of English and areas of the curriculum such as life sciences, history, and so on. As teachers participate in these projects, they can improve their $\mathrm{L} 2$ competence, expand their repertoire of $L 2$ instructional tasks and deepen their knowledge of $L 2$ pedagogical principles (Hansen-Thomas \& Grosso, 2015). Also, as their learners face the integration of $L 2$ and subject-matter learning in these $L 2$ teacher education projects, they can realize the importance of $L 2$ learning, develop $L 1$ and $L 2$ academic skills and increase their self-confidence (Arias \& Izquierdo, 2015). In turn, this type of $L 2$ teacher education initiatives could have positive implications for the enactment of $L 2$ educational policies among generalist teachers and scaffold the effective implementation of English language education in rural schools.

\section{Acknowledgements}

We are grateful to the school superintendents, principals and teachers. We also thank Lisseth Cuevas, Darcy Stock and the journal editor and reviewers for their valuable feedback on earlier versions of this manuscript. 
References

Arias, A., \& Izquierdo, J. (2015). Language attention in content-based instruction: The case of language instructors teaching content in a foreign language in Mexican higher education. Journal of Immersion and ContentBased Language Education, 3(2), 194-217.

Bonilla, S., \& Cruz-Arcila, F. (2014). Critical socio-cultural elements of the intercultural endeavor of English teaching in Colombian rural areas. Profile, 16(2), 117-133.

Bryan, L., \& M cLaughlin, H. (2005). Teaching and learning in rural M exico: A portrait of student responsibility in everyday school life. Teaching and Teacher Education, 21, 33-48.

Carr, W. (1999). Fear of teaching French: Challenges faced by generalist teachers. Canadian Modern Language Review, 56(1),155-179.

Coelho, F., \& Henze, R. (2014). English for what? Rural Nicaraguan teachers' local responses to national educational policy. Language Policy, 13(2), 145-163. https://doi.org/10.1007/s10993-013-9309-4.

Creswell, J. (2018). Research design. Qualitative, quantitative and mixed-methods approaches. Sage.

Crystal, D. (2012). English as a global language. Cambridge University Press.

Field, A. (2017). Discovering statistics using IBM SPSS statistics. North American edition. Sage

Giannikas, C. (2011). L1 in English language learning: A research study in a Greek regional context. International Journal of Applied Linguistics, 21(3), 319-339.

Hancock, C., \& Scherff, L. (2010). Who will stay and who will leave? Predicting secondary English teacher attrition risk. Journal of Teacher Education, 61(4), 328-338.

Hansen-Thomas, H., \& Grosso, L. (2015). ESL mentoring for secondary rural educators: $M$ ath and science teachers become second language specialists through collaboration. TESOL Journal, 6(4), 766-776.

Hansen-Thomas, H., Grosso, L., Kakkar, K., \& Okeyo, C. (2016). I do not feel I am properly trained to help them! Rural teachers' perceptions of challenges and needs with English-language learners. Professional Development in Education, 42(2), 308-324.

Hernández, M., \& Izquierdo, J. (2020). Cambios curriculares y enseñanza del inglés: Cuestionario de percepción docente. Sinéctica, Revista Electrónica de Educación, 54, 1-22.

Hossain, M. (2016). English language teaching in rural areas: A scenario and problems and prospects in context of Bangladesh. Advances in Language and Literacy Studies, 7(3), 1-12. 
Izquierdo, J., García, V., Garza, G., \& Aquino, S. (2016). First and target language use in public language education for young learners: Longitudinal evidence from M exican secondary-school classrooms. System, 61, 20-30.

Kihlstedt, M. (2019). Foreign language teaching and learning in primary schools in Europe: Beliefs and realities. Emerging Trends in Education, 2(3), 71-96. Kissau, S., Davin, K., \& Wang, C. (2019). Aspiring world language teachers: Their influences, perceptions, and commitment to teaching. Teaching and Teacher Education, 78, 174-182.

König, J., Lammerding, S., Nold, G., Rohde, A., Strauss, S., \& Tachtsoglou, S. (2016). Teachers' professional knowledge for teaching English as a foreign language: Assessing the outcomes of teacher education. Journal of Teacher Education, 67(4), 320-337. Lamb, M. (2012). A self system perspective on young adolescents' motivation to learn English in urban and rural settings. Language Learning, 62, 997-1023. Lightbown, P., \& Spada, N. (2020). Teaching and learning L2 in the classroom: It's about time. Language Teaching, 53(1), 1-11.

Pinzón, R. (2014). English teaching through project-based learning method in rural area. Cuadernos de lingüística hispánica, 23, 151-170.

Ramos Holguín, B., \& Aguirre Morales, J. (2016). English language teaching in rural areas: A new challenge for English language teachers in Colombia. Cuadernos de Lingüística Hispánica, 27, 209-222.

Roldán, A., \& Peláez, O. (2017). Engl ish language policy in a Colombian rural area: A case study in Antioquia. Ikala, Revista de Lenguaje y Cultura, 22(1), 121-139.

Saulés, S. (2012). La competencia lectora en pisa. Influencias, innovaciones y desarrollo. INEE.

SE. (2011). M odelo educativo para el fortalecimiento de telesecundaria. Documento base. Secretaría de Educación Pública, M exico.

SE. (2016). M anual para la Aplicación, Calificación, Análisis y Uso de los Resultados de la Prueba. Planea Educación Básica, Tercer Grado de Secundaria, 2016. Secretaría de Educación Pública (SEP), Instituto Nacional para la Evaluación de la Educación (INEE).

SE. (2017). Estadística del sistema educativo Tabasco. Ciclo escolar 2016-2017. Sistema Nacional de Información Estadística Educativa, Mexico.

Woodend, J., Fedoruk, L., Beek, A., Roy, S., Xu, X., Groen, J., \& Li, X. (2019). The privileging of English language use in academia: Critical reflections from an international doctoral seminar. Emerging Trends in Education, 2(3), 1-22.

Yunus, M ., \& Abdullah, N. (2011). M otivation and attitudes for learning English among year six students in primary rural school. Procedia Social and Behavioral Sciences, 15, 2631-2636.

Zein, M. S. (2017). Elementary English education in Indonesia: Policy developments, current practices, and future prospects. English Today, 33(1), 53-59. 


\section{APPENDIX}

\section{English Language Professionalization Survey for Generalist Teachers in Rural Secondary Schools}

Teacher's Name

\section{TEACHING EXPERIENCE}

1. Please indicate the year that you started working as a teacher in tele-secondary education in the Southeast of M exico:

2. Underline the grades that you have taught in the public secondary schools of the Southeast of Mexico.
a) Grade 1
b) Grade 2
c) Grade 3

3. Underline the grade you currently teach at your tele-secondary school.
a) Grade 1
b) Grade 2
c) Grade 3

4. Underline the grade that you are at most at ease teaching English in tele-secondary education.
a) Grade 1
b) Grade 2
c) Grade 3

\section{CURRICULAR KNOWLEDGE}

5. Are you aware of the curricular basis that supports English learning in secondary education in the 2011 Curriculum and syllabus for the basic education levels (i.e., kindergarten, elementary and secondary education)?
a) Yes
b) No

6. Are you aware of the Common European Framework's English benchmarks that secondary school students must reach, according to the 2011 Curriculum and syllabus?
a) Yes
b) No

7. Are you aware of the pedagogical approach that supports English learning and teaching in tele-secondary education?
a) Yes
b) $\mathrm{No}$

\section{DIDACTIC M ATERIALS}

8. Do you use in your English classes the didactic materials that are available at the website www.telesecundaria.sep.gob.mx to teach this language in tele-secondary schools?
a) Yes
b) No

9. If you use the didactic materials that are available at the website www.telesecunda ria.sep.gob.mx, underline the reasons that motivate yourself to do so.

- They are easy for me to understand.

- $\quad$ They are easy for my students to understand.

- They are available in my school.

- My school has the appropriate technological resources for their implementation.

- My school has the appropriate infrastructure for their implementation. 
- It motivates students to learn English.

10. If you don't use the didactic materials that are available at the website www.telesecund aria.sep.gob.mx, underline the reasons that push you to do this.

- They are difficult for me to understand.

- They are difficult for my students to understand.

- They are not available in my school.

- Myschool doesnot have the appropriate technological resourcesfor their implementation.

- My school does not have the appropriate infrastructure for their implementation.

- It does not motivate students to learn English.

11. Have you attended some training about how to employ the didactic materials that are available at the website www.telesecundaria.sep.gob.mx to teach English in tele-secondary schools?
a) Yes
b) No

\section{KNOWLEDGE OF THE ENGLISH LANGUAGE}

12. Underline the educational levels in which you underwent obligatory English lessons.
a) Public secondary
d) Private primary
g) Private university
b) Public preparatory
e) Private secondary
c) Public university
f) Private preparatory

13. Underline other educational options that you have reached out to in order to improve your English knowledge.

a) University language schools. How many semesters?

b) Private institutions such as Harmon Hall, English Point, etc. How many semesters?

c) Autonomously. How many months?

d) English courses provided by the M inistry of Education for tele-secondary school teachers. Approximate duration in hours:

e) Other (please indicate which):

\section{ENGLISH LANGUAGE TEACHING TRAINING}

14. Check the training/ education that you possess in relation to English language teaching. a) English language teaching courses organized by the M inistry of Education for tele-secondary school teachers. Approximate duration of hours:

b) English language teaching courses not organized by the M inistry of Education for telesecondary school teachers. Approximate duration of hours:

c) I haven't taken any courses related to the teaching of the English language.

d) Workshops, conferences or congresses about English language teaching organized by the M inistry of Education for tele-secondary school teachers. Approximate duration of hours:

e) Workshops, conferences or congresses about English language teaching not organized by the Ministry of Education for tele-secondary school teachers. Approximate duration of hours: 
f) I haven't participated in any workshop, conferences or congresses about English language teaching.

\section{WIUNGNESSTO PARTICIPATE IN ENGUSH LANGUAGE LEARNING ANDTEACHING COURSES}

15. Are you interested in taking a course to improve your English language proficiency?
A) Yes
B) No

16. Are you interested in taking a course related to English language teaching?
A) Yes
b) No

17. Are you interested in taking a course related to the available online English-language instructional materials concerning tele-secondary education?
A) Yes
B) $\mathrm{No}$

THANK YOU VERY MUCH! () 